\title{
The X-Ray Crystal Structure of the Acylated Species of the $\square$-Lactam Sensor Domain of BlaR1 from Staphylococcus aureus and the Mechanism of Receptor Activation for Signal Transduction
}

\author{
Catherine Birck†, Joo Young Cha $\neq$, Jason Crossy, Clemens Schulze-Briese §, Samy O. Meroueh $\neq$, H. \\ Bernhard Schlegelf, Shahriar Mobashery** and Jean-Pierre Samama †*
}

† Département de Biologie et Génomique structurale, IGBMC, 1 rue Laurent Fries, BP10142, Illkirch, France; $\ddagger$ Department of Chemistry and Biochemistry, University of Notre Dame, Notre Dame, Indiana 46556; ๆ Department of Chemistry, Wayne State University, Detroit, MI, 48202; § Swiss Light Source at Paul Scherrer Institut, CH-5232 Villigen PSI.

AUTHOR EMAIL ADDRESS mobashery@nd.edu and samama@titus.u-strasbg.fr

RECEIVED DATE (to be automatically inserted after your manuscript is accepted if required according to the journal that you are submitting your paper to)

\section{Supporting Information}

\section{Materials and Methods}

Seleno-Methionine and other reagents were purchased from Sigma, unless otherwise stated. $\mathrm{NaH}^{13} \mathrm{CO}_{3}$ (99\% enriched) was purchased from Cambridge Isotope Lab. Escherichia coli B834(DE3) was from Novagen.

Preparation and Purification of Seleno-Methionine-Labelled sensor domain of BlaR1. The pET24a+ vector, which harbors the cloned blaR C-terminal domain gene (blaR $\left.{ }^{S}\right)$ was constructed previously. ${ }^{1}$ We transformed E. coli B834(DE3), a methionine auxotroph, with this plasmid. The cells were cultured in M9 minimal media supplemented with seleno-methionine. All the ingredients for M9 media were either autoclaved or filtered for use. First, 5x M9 medium $\left(32 \mathrm{~g} \mathrm{Na}_{2} \mathrm{HPO}_{4} .7 \mathrm{H} 2 \mathrm{O}, 7.5 \mathrm{~g} \mathrm{KH}_{2} \mathrm{PO}_{4}\right.$, $1.25 \mathrm{~g} \mathrm{NaCl}, 2.5 \mathrm{~g} \mathrm{NH}_{4} \mathrm{Cl} / 500 \mathrm{ml} \mathrm{H} 2 \mathrm{O}$ ) and 5x amino acid solution (L-enantiomer, $100 \mathrm{mg}$ of each alanine, arginine. $\mathrm{HCl}$, aspartic acid, cystine, glutamic acid, glutamine, glycine, histidine, isoleucine, leucine, lysine. $\mathrm{HCl}$, phenylalanine, proline, serine, threonine, tyrosine, valine in $500 \mathrm{~mL}$ of water) was prepared and autoclaved. The final M9 media contained 1x M9 media, 1x amino acid solution, $2 \mathrm{mM} \mathrm{MgSO}, 0.1 \mathrm{mM}$ $\mathrm{CaCl}_{2}, 1 \mu \mathrm{M} \mathrm{FeCl}_{3}, 0.4 \%$ glucose, $0.4 \mathrm{M}$ sorbitol, $2.5 \mathrm{mM}$ betaine. E. coli B834(DE3) harboring pET24a+ vector with cloned blaRS was inoculated in $150 \mathrm{~mL}$ of LB medium containing $30 \mu \mathrm{g} / \mathrm{mL}$ of kanamycin and was allowed to grow overnight at $37{ }^{\circ} \mathrm{C}$. The cells were harvested to remove the medium and were resuspended with the M9 medium with the supplements. These cells were mixed with 3L of the M9 minimal medium supplemented with $30 \mu \mathrm{g} / \mathrm{mL}$ kanamycin. The culture was grown at $37{ }^{\circ} \mathrm{C}$ to an $\mathrm{A} 600$ of $\sim 0.8$ and then was cooled to $25^{\circ} \mathrm{C}$. The cells were induced with $0.4 \mathrm{mM}$ IPTG and the suspension was shaken at $25^{\circ} \mathrm{C}$ for 20 hours. The isolation and purification steps were carried out as described earlier. ${ }^{1}$ Electrospray mass spectrometry of the purified protein established that nine methionine residues, excluding the cleaved $N$-terminal methionine, were replaced by selenomethionine.

Crystallization and Data Collection. The sensor domain of BlaR1 in $10 \mathrm{mM}$ Tris (pH 7.0) was concentrated to $15 \mathrm{mg} / \mathrm{mL}(0.5 \mathrm{mM})$ by using a Centricon-10 devise (Millipore). Crystals were grown at $22{ }^{\circ} \mathrm{C}$ using the hanging-drop vapor diffusion method. Crystals of BlaR1-ceftazidime complexes were obtained by mixing $1 \mu \mathrm{L}$ containing $0.5 \mathrm{mM}$ of the enzyme and $5 \mathrm{mM}$ ceftazidime, with $1 \mu \mathrm{L}$ of a reservoir solution containing 12\% Polyethylene Glycol Monomethyl Ether 5000, 0.2 M lithium sulfate, $0.1 \mathrm{M}$ HEPES (pH 7.0) and 0.2 CMC nonyl- $-\mathrm{D}$-glucoside. Single crystals appeared in one day and grew to a 
maximum size of $0.8 \times 0.6 \times 0.2 \mathrm{~mm} 3$ in five days. Crystals were soaked in cryo-protectant $(15 \%$ ethyleneglycol in the reservoir solution) for $10 \mathrm{~s}$ and then flash-cooled in liquid nitrogen. Crystals belong to the space group $\mathrm{p} 21$ with unit cell parameters of $\mathrm{a}=59.20 \AA, \mathrm{b}=109.79 \AA$ and $\mathrm{c}=91.60 \AA$, and $\square=$ $106.12^{\circ}\left(\mathrm{a}=59.38 \AA, \mathrm{b}=109.47 \AA\right.$ and $\mathrm{c}=91.08 \AA$, and $\square=106.48^{\circ}$ for the SeMet-BlaR-ceftazidime complex) with four molecules in the asymmetric unit. Diffraction data were collected on the X06SA synchrotron beamline at Swiss Light Source (Villigen, Switzerland). With the Se-crystals, multiwavelength anomalous diffraction (MAD) data were collected at the selenium K absorption edge $(\square=0.9793 \AA$, minimum of $\left.\mathrm{f}^{\prime}\right)$, at the peak $\left(\square=0.9790 \AA\right.$, maximum of $\left.\mathrm{f}^{\prime \prime}\right)$, and at a high-energy remote $(\square=0.9184 \AA)$. With the native crystals, two sets of data, at high and low resolution, were collected at a wavelength of $0.9794 \AA$. Intensity data were processed and scaled using HKL 2000 (Se-complexes) or mosflm/scala/truncate (native complexes) and are summarized in Table1.

Structure Determination and Model Refinement. The structure of SeMet-BlaR 1 complex was solved by the single anomalous diffraction (SAD) method using diffraction data to $2.2 \AA$. The program SOLVE was used to find thirty of the thirty-six possible selenium sites and obtain the initial protein phases. The program RESOLVE was used to improve phases through density modification assuming a solvent content of $48 \%$ and to fit $71 \%$ of the residues in the electron density map. The remainder of the structure was built manually using TURBO-FRODO. Refinement in CNS led to Rcryst and Rfree values of 25.6 and $27.6 \%$, respectively, for all data to $2.2 \AA$. The Se-BlaR structure was used as a starting model for rigid body refinement in CNS using the native data set. After torsion angle simulated annealing and Bfactor refinements, the model was manually corrected using $2 \mathrm{Fo}-\mathrm{Fc}$ sigmaA-weighted electron density maps displayed with TURBO. Water molecules and the ligands in the active sites were then modeled. Further refinement in CNS led to Rcryst and Rfree values of $20.6 \%$ and $23.4 \%$, respectively, for all data to $1.75 \AA$ A (Table 1). The final model comprised four BlaR1 monomers, with Ser-389 acylated by ceftazidime, 2 sulfate anions, one 4-(2-hydroxyethyl)piperazine-1-ethanesulfonic acid (HEPES) molecule and 277 water molecules. The stereochemistry of the models were verified using the program PROCHECK. Figures were generated with MOLSCRIPT and RASTER3D.

Table 1. Data collection and refinement statistics

\begin{tabular}{|c|c|c|c|c|}
\hline & \multicolumn{2}{|c|}{$\begin{array}{c}\text { BlaR1-ceftazidime complex } \\
\text { (SeMet protein) } \\
\left(\square_{\text {peak }}=0.9790 \AA\right)\end{array}$} & \multicolumn{2}{|c|}{$\begin{array}{l}\text { BlaR1-ceftazidime complex } \\
\text { (native protein) } \\
(\square=0.9794 \AA)\end{array}$} \\
\hline & $50.0-1.90 \AA$ & $1.97-1.90 \AA$ & $69.0-1.75 \AA$ & $1.84-1.75 \AA$ \\
\hline number of observations & 286,716 & 24,943 & 687,858 & 51,481 \\
\hline number of unique reflections & 84,427 & 8,056 & 110,752 & 15,412 \\
\hline multiplicity & 3.4 & 3.1 & 4.2 & 3.3 \\
\hline completeness $(\%)$ & 91.5 & 83.8 & 98.0 & 98.0 \\
\hline $\mathrm{R}_{\mathrm{sym}}$ & 0.073 & 0.239 & 0.070 & 0.260 \\
\hline $\mathrm{I} / \square$ & 10.4 & 3.1 & 6.0 & 2.7 \\
\hline $\mathrm{R}_{\text {factor }}$ & & & & 205 \\
\hline $\mathrm{R}_{\text {free }}$ & & & & 234 \\
\hline Rmsd for bond length $(\AA)$ & & & & 021 \\
\hline Rmsd for bond angle $\left(^{\circ}\right)$ & & & & .88 \\
\hline Dihedrals $\left({ }^{\circ}\right)$ & & & & 4.0 \\
\hline
\end{tabular}



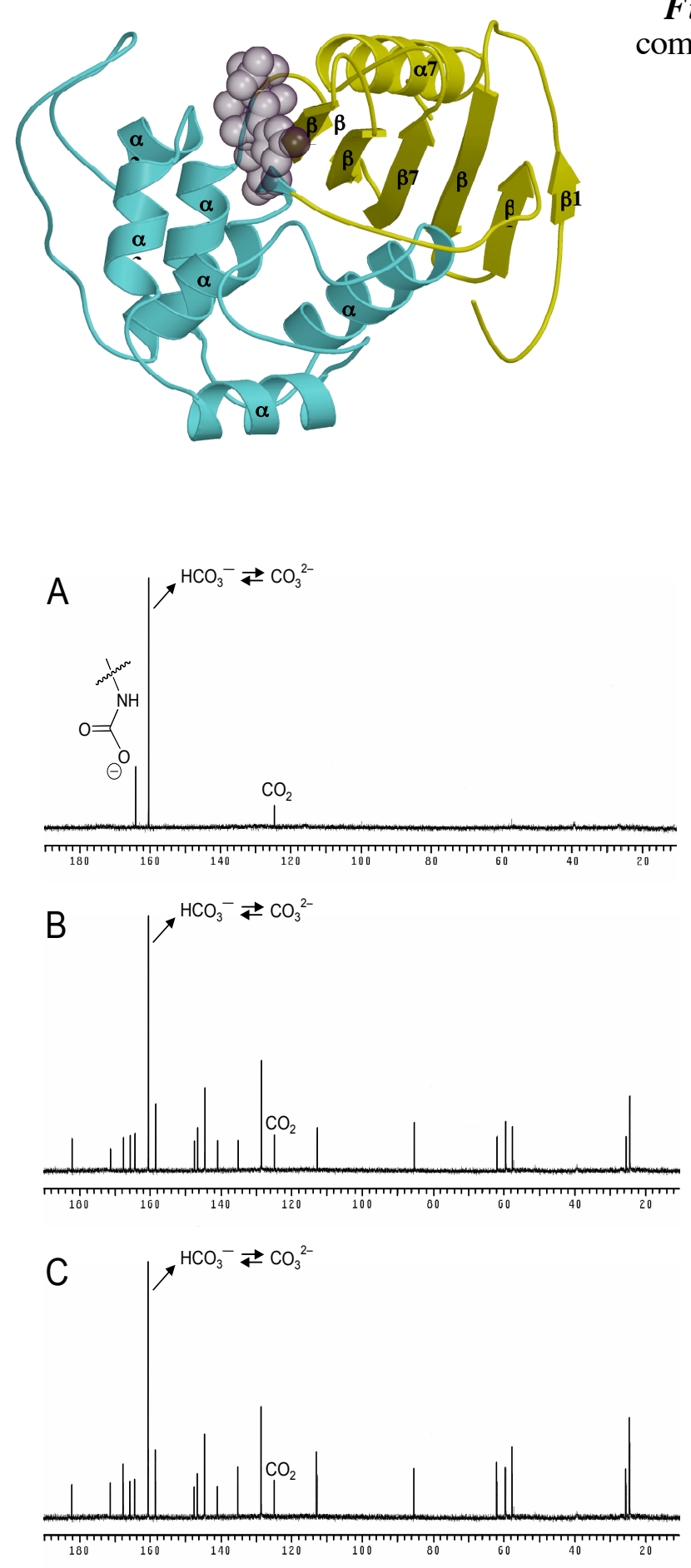

Figure 1. The ribbon drawing of the BlaR1-ceftazidime complex
Figure 2. (A) ${ }^{13} \mathrm{C}$-labeled (99\% enriched) wild-type BlaR1 (1 mM) in Buffer I, (B) $28 \mathrm{mM}$ of natural abundance isotopes of ceftazidime added to ${ }^{13} \mathrm{C}$-labled wild-type BlaR1 in Buffer I, (C) $28 \mathrm{mM}$ of natural abundance isotopes of ceftazidime by itself in Buffer I (D) $200 \mathrm{mM}$ of natural abundance isotopes of oxacillin with ${ }^{13} \mathrm{C}$-labeled (99\% enriched) wild-type BlaR1 in Buffer I, (E) $200 \mathrm{mM}$ of natural abundance isotopes of oxacillin by itself in Buffer I. The $\mathrm{pH}$ in each case was adjusted after all reagents were mixed. The entire absence of the signal at $164 \mathrm{ppm}$ in the case of ceftazidime (panel B) and a mere remnant in the case of oxacillin (panel D) is noted, despite the presence of high concentrations of both bicarbonate and carbon dioxide in the NMR tube. The rest of all the resonances can be accounted for by the NMR resonances for the structures of the antibiotics themselves.
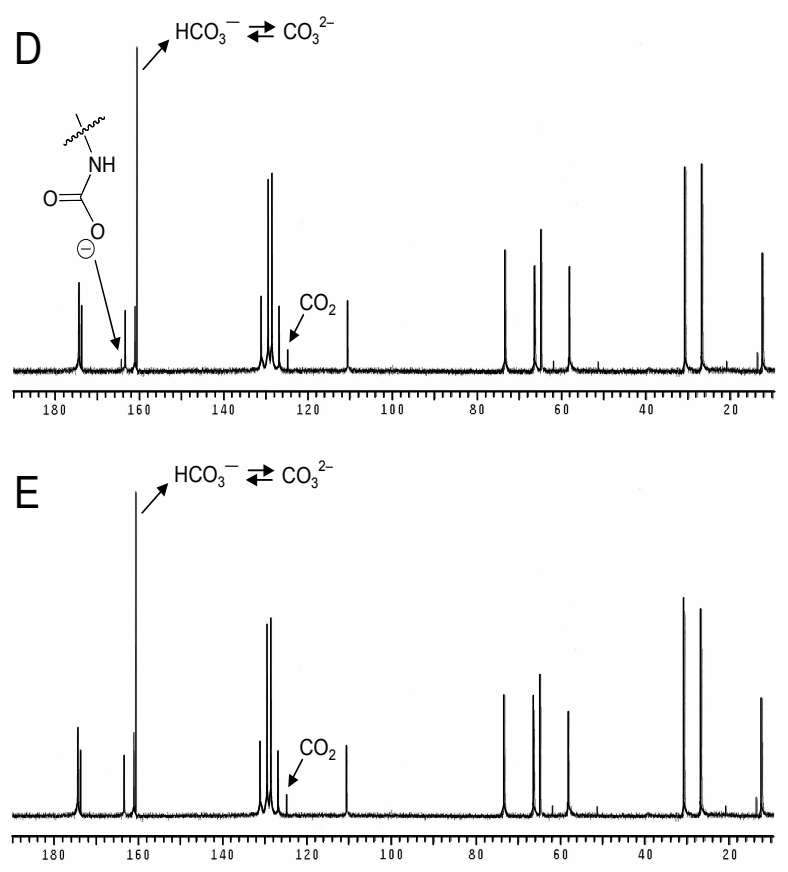
NMR measurements. Each buffer for this preparation was degassed before use. A total of $10 \mathrm{mg}$ of wild-type BlaR1 was incubated with several changes of $25 \mathrm{mM}$ sodium acetate buffer ( $\mathrm{pH} 4.5)$ to release $\mathrm{CO} 2$ from active site. Then, the sample was incubated with several changes of $10 \mathrm{mM}$ sodium phosphate buffer, containing $1 \mathrm{mM}$ EDTA ( $\mathrm{pH}$ 7.5) to restore the $\mathrm{pH}$ to the original value. Finally, the sample was incubated with $10 \mathrm{mM}$ sodium phosphate buffer, containing $1 \mathrm{mM}$ EDTA, $20 \mathrm{mM} \mathrm{NaH}{ }^{13} \mathrm{CO}_{3}$ and $10 \%$ $\mathrm{D}_{2} \mathrm{O}, \mathrm{pH} 7.5$ (Buffer I) and concentrated up to $1 \mathrm{mM}$ just prior to the experiment by a centrifugal filter device (5 kDa, Millipore). Each antibiotic was added to the concentrated protein immediately prior data measurements.

Determination of Partition Ratio. The method of Mobashery et al. was used. ${ }^{2}$ BlaR1 (1.8 $\left.\mu \mathrm{M}\right)$ was added to ceftazidime (concentrations varying from 0 to $10 \mu \mathrm{M}$ ) in $100 \mathrm{mM}$ sodium phosphate, $50 \mathrm{mM}$ sodium bicarbonate, $\mathrm{pH}$ 7.0. The reaction mixtures were incubated at room temperature for one minute (exceeding many times the $t 1 / 2$ of acylation, which is $170 \mathrm{~ms}$ ). Bocillin FL, a fluorogenic substrate of BlaR1, was added to each sample to a concentration of $20 \mu \mathrm{M}$ in a final volume of $20 \mu \mathrm{L}$. The mixtures were incubated at $37{ }^{\circ} \mathrm{C}$ for $5 \mathrm{~min}$, at which point the reactions were quenched by addition of $15 \mu \mathrm{L}$ of the SDS sample buffer (125 mM Tris, 4\% SDS, 20\% glycerol, 2\% 2-mercaptoethanol, pH 6.8), and boiled for 4 min. The samples were loaded onto $15 \%$ SDS-PAGE, the gel was developed and scanned using a Storm $840 \square$ Fluorimager. The fluorescent bands of bocillin FL-labelled BlaR1 were analyzed by Image Quant 5.2 software.

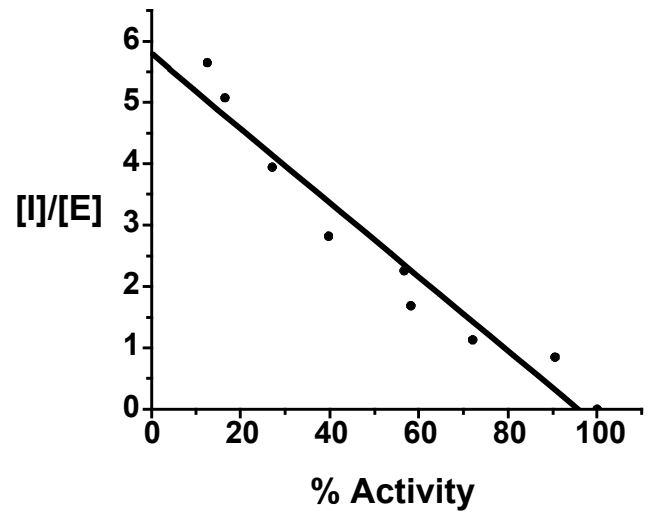

Figure 3. Determination of partition ratio of BlaR1 with ceftazidime.

Quantum Mechanical/Molecular Mechanical calculations. Molecular orbital calculations were carried out using a development version of the GAUSSIAN series of programs. ${ }^{3}$ The high-resolution structure of the OXA-10 -lactamase was obtained from the Research Collaboratory for Structure Bioinformatics database (RCSB; http://www.rcsb.org/pdb/index.html) with accession number 1K55. Manipulation of the structure was carried out with the Sybyl 6.7 package $^{4}$ and the AMBER 6 suite of programs. ${ }^{5}$ Atomic charges of the carboxylated lysine were computed using the two-stage RESP fitting procedure. ${ }^{6}$ The protein was then immersed in a box of TIP3P water with at least $10 \AA$ between any face of the box and the enzyme. Water molecules were equilibrated by running a $30 \mathrm{ps}$ molecular dynamics simulation, while holding the protein fixed. This was followed by 20,000 steps of conjugate-gradient energy minimization of the entire system. The resulting structure, which included water molecules within $12 \AA$ from the carboxylated lysine and $3 \AA$ from any other residue at the surface of the protein, was used for the QM/MM calculations. A two layer ONIOM method ${ }^{7,8}$ with electrostatic embedding ${ }^{9,10}$ was used for mixed quantum/classical (QM/MM) calculations. Hydrogen atoms were used as link atoms to cap any bonds that were cut in forming the model region. The quantum calculations on the model system were carried out at the B3LYP/6-31G(d,p) level of theory, while the AMBER force field with the "parm96" set of parameters ${ }^{11}$ was used for molecular mechanics computations on the low-level, classical calculations. The $\mathrm{C} \square, \mathrm{C} \square$ and $\mathrm{N} \square$ atoms (and associated $\mathrm{H}$ atoms) of the Lys-70 side chain and the atoms of the $\mathrm{CO}_{2}$ molecule were incorporated into the quantum layer. The majority of the protein was held fixed in Cartesian 
space, allowing only 49 atoms within the immediate active-site region to move during the geometry optimization. Since the carboxylation/decarboxylation takes place in a localized part of the enzyme, this reduced the numerical noise in the relative energies due to conformational changes at a distance from the active site.

\section{References}

(1) Golemi-Kotra, D.; Cha, J. Y.; Meroueh, S. O.; Vakulenko, S. B.; Mobashery, S. Journal of Biological Chemistry 2003, 278, 18419-18425.

(2) Mobashery, S.; Ghosh, S. S.; Tamura, S. Y.; Kaiser, E. T. Proc Natl Acad Sci U S A 1990, 87, 578582.

(3) Frisch, M. J.; Trucks, G. W.; Schlegel, H. B.; Scuseria, G. E.; Robb, M. A.; Cheeseman, J. R.; Montgomery, J. A.; Vreven, T.; Kudin, K. N.; Burant, J. C.; Millam, J. M.; Iyengar, S.; Tomasi, J.; Barone, V.; Mennucci, B.; Cossi, M.; Scalmani, G.; Rega, N.; Petersson, G. A.; Ehara, M.; Toyota, K.; Hada, M.; Fukuda, R.; Hasegawa, J.; Ishida, M.; Nakajima, T.; Kitao, O.; Nakai, H.; Honda, Y.; Nakatsuji, H.; Li, X.; Knox, J. E.; Hratchian, H. P.; Cross, J. B.; Adamo, C.; Jaramillo, J.; Cammi, R.; Pomelli, C.; Gomperts, R.; Stratmann, R. E.; Ochterski, J.; Ayala, P. Y.; Morokuma, K.; Salvador, P.; Dannenberg, J. J.; Zakrzewski, V. G.; Dapprich, S.; Daniels, A. D.; Strain, M. C.; Farkas, Ö.; Malick, D. K.; Rabuck, A. D.; Raghavachari, K.; Foresman, J. B.; Ortiz, J. V.; Cui, Q.; Baboul, A. G.; Clifford, S.; Cioslowski, J.; Stefanov, B. B.; Liu, G.; Liashenko, A.; Piskorz, P.; Komaromi, I.; Martin, R. L.; Fox, D. J.; Keith, T.; Al-Laham, M. A.; Peng, C. Y.; Nanayakkara, A.; Challacombe, M.; Gill, P. M. W.; Johnson, B.; Chen, W.; Wong, M. W.; Andres, J. L.; Gonzalez, C.; Head-Gordon, M.; Replogle, E. S.; Pople, J. A.; Revision B.02 ed.; Gaussian, Inc.: Pittsburgh, PA, 2002.

(4) Tripos, I.; Sybyl 6.7 ed.: 1699 Sourth Hanley Rd., St. Louis, Missouri, 63144, USA.

(5) Case, D. A.; Pearlman, D. A.; Caldwell, J. W.; Cheatham III, T. E.; Ross, W. S.; Simmerling, C. L.; Darden, T. A.; Merz, K. M.; Seibel, G. L.; Cheng, A. L.; Vincent, J. J.; Crowley, M.; Tsui, V.;

Radmer, R. J.; Duan, Y.; Pitera, J.; Massova, I.; Seibel, G. L.; Singh, U. C.; Weiner, P. K.; Kollman, P. A.; University of California: San Francisco, 1999.

(6) Bayly, C. I.; Cieplak, P.; Cornell, W. D.; Kollman, P. A. J. Chem. Phys. 1993, 97, 10269-10280.

(7) Maseras, F.; Morokuma, K. J. Comput. Chem. 1995, 16, 1170-1179.

(8) Dapprich, S.; Komaromi, I.; Byun, K. S.; Morokuma, K.; Frisch, M. J. J. Mol. Struct.THEOCHEM 1999, 462, 1-21.

(9) Vreven, T.; Morokuma, K.; Farkas, O.; Schlegel, H. B.; Frisch, M. J. J. Comput. Chem. 2003, 24, 760-769.

(10) Vreven, T.; Morokuma, K. Theor. Chem. Acc. 2003, 109, 125-132.

(11) Kollman, P. A.; Dixon, R.; Cornell, W. D.; Fox, T.; Chipot, C.; Pohorille, A. In Computation Simulations of Biomolecular Systems; Wilkinson, A., Weiner, P., van Gunsteren, W., Eds.; Elsevier, 1997; Vol. 3, pp 83-96. 